\title{
Cause and effect relationships, multivariate approach for inoculation of Azospirillum brasilense in corn
}

\author{
Luiz Leonardo Ferreira ${ }^{1}$, Gean Ferreira Santos ${ }^{1}$, Ivan Ricardo Carvalho ${ }^{2 *}$, Marilaine de Sá Fernandes ${ }^{1}$, \\ Ariana Bertola Carnevale ${ }^{1}$, Karine Lopes ${ }^{1}$, Roselaine Lages Fonseca Prado ${ }^{1}$, Francine Lautenchleger ${ }^{3}$, \\ Alexandre Igor de Azevedo Pereira ${ }^{4}$ and Carmen Rosa da Silva Curvêlo ${ }^{4}$
}

\author{
${ }^{1}$ Centro Universitário de Mineiros, Unidade de Biociências, GO, Brazil. \\ ${ }^{2}$ Universidade Regional do Noroeste do Estado do Rio Grande do Sul, \\ Departamento de Estudos Agrários, RS, Brazil. \\ ${ }^{3}$ Universidade do Centro-Oeste (UNICENTRO), Guarapuava, PR, Brazil. \\ ${ }^{4}$ Instituto Federal Goiano, IF Goiano, Urutaí, Mineiros, GO, Brazil. \\ *Author for correspondence: carvalho.irc@gmail.com
}

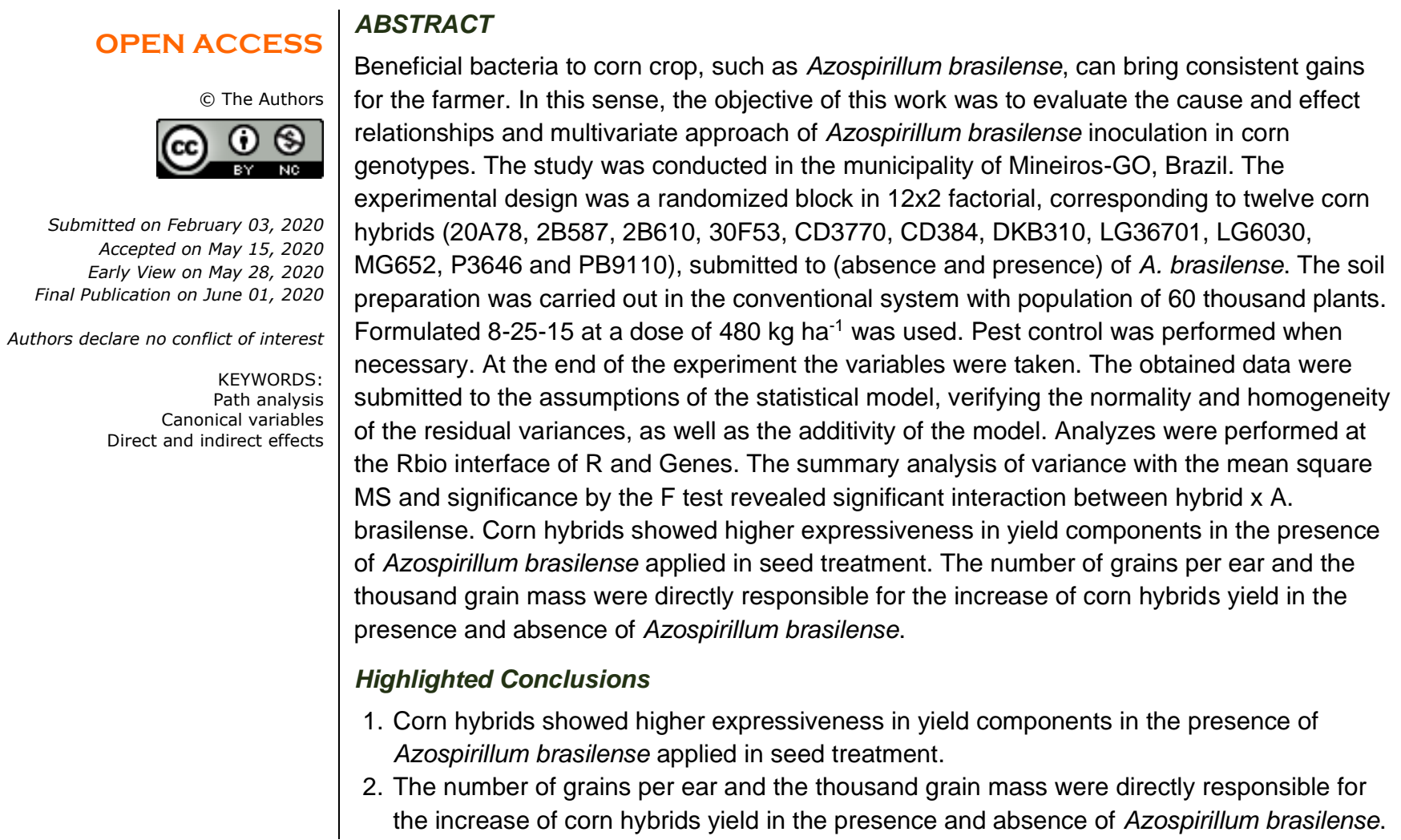

\section{INTRODUCTION}

Corn (Zea mays L.) belongs to the Poaceae family and is a North American species with a genetic origin in Mexico and is intended for in natura consumption for animal and human consumption (Silveira et al. 2015). Corn also contributes to the competitiveness of important production chains such as meat and allows Brazil to supply this food to important consumer markets (Freitas et al. 2017). In recent years, corn cultivation in Brazil has been undergoing important changes in crop management, which has resulted in significant increases in grain yield (Farinelli and Cerveira Junior 2015). The scenario of off-season crop corn in recent years has changed, since in the 1980 s it was unrepresentative, associated with low yields. However, due to the reach of technological advances, it has become one of the fastest growing crops in productivity and expansion of cultivated area in Brazil. It has been generally grown after early soybean, which has been considered the main crop for many farmers (Corsini 2018). In the 2017/18 harvest, Brazil produced 87,279.0 thousand tons of corn grain, with the first crop reaching 25,121.2 
thousand tons of grain, $28.8 \%$ of total corn production, and the off-season crop with $62,158.1$ thousand tons of corn grains, $71.2 \%$ of total corn production (CONAB 2018).

The use of inoculants containing plant growth-promoting bacteria may be one of the existing alternatives to increase the efficiency of chemical fertilizer use, which may lead to a decrease in the amount applied in agricultural production environments (Spolaor et al. 2016). Beneficial bacteria to corn cultivation, such as Azospirillum brasilense, can bring consistent gains to the farmer without the need for large investments with chemical fertilizers, particularly nitrogenous ones. Tests conducted in Londrina and Ponta Grossa found an average yield gain from $24 \%$ to $30 \%$ increase in yields compared to uninoculated control (Ribeiro 2015). According to Dall'agnol et al. (2018), the inoculation of corn with Azospirillum, either via seeds, sowing furrow or foliar application, increases the efficiency of nitrogen fertilizer use, which, depending on certain conditions, may allow a reduction in the amount of $\mathrm{N}$ applied for topdressing on corn. The percentage of reduction will depend on the technological level employed, the productive potential and the climatic risks to the crop.

Azospirillum is a free-living soil bacterium that has a good ability to associate biological nitrogen with plants, but without the complexity of nodule formation. It is believed that the population of Azospirillum may vary from hybrid to hybrid, depending on the different qualitative and quantitative characteristics of root exudates (Cadore 2016). Therefore, evaluations that point out the real influence of bacteria on the plant are extremely relevant; knowing how and at what point in its development the plant is benefiting can be an important tool for the correct use of technology and a greater adoption, especially by the production chain, of inoculating plants with growth-promoting bacteria (Corsini 2018). The objective of this work was to evaluate the cause and effect relationships and multivariate approach of Azospirillum brasilense inoculation in corn genotypes.

\section{MATERIAL AND METHODS}

The study was conducted at Luiz Eduardo de Oliveira Sales Experimental Farm, in the municipality of Mineiros-GO, located between the geographic coordinates of $17^{\circ} 34^{\prime} 10^{\prime \prime}$ South latitude and $52^{\circ} 33^{\prime} 04$ " West longitude, with an average altitude of $760 \mathrm{~m}$. While conducting the experiment, it was verified the temperature averages: $20.55^{\circ} \mathrm{C}$, relative air humidity: $80 \%$, dew point: $16.9^{\circ} \mathrm{C}$, atmospheric pressure: $934.25 \mathrm{hPa}$, wind speed: $0.75 \mathrm{~m} \mathrm{~s}^{-1}$, and rainfall: $608.8 \mathrm{~mm}$. The experimental area is classified as an Aw hot dry climate (Köppen 1943). The soil of the experimental area was classified as Arenosol, with medium texture, gently wavy to flat topography and limited good (Embrapa 2013).

The experimental design was a randomized block in a $12 \times 2$ factorial design, totaling 24 treatments, corresponding to twelve corn hybrids (20A78, 2B587, 2B610, 30F53, CD3770, CD384, DKB310, LG36701, LG6030, MG652, P3646 and PB9110), submitted to (absence and presence) of $A$. brasilense formulated with strains $\mathrm{Ab}-\mathrm{V} 5$ and $\mathrm{Ab}-\mathrm{V} 6$ with viable cell concentration of $10 \times 82$ in seed treatment, in 4 replications, totaling 80 experimental units, where each unit was composed of 3 rows of $1.5 \mathrm{~m}$ length distanced every $0.5 \mathrm{~m}$ and density of 4 grains per linear $\mathrm{m}$, relating a population of 60,000 plants $\mathrm{ha}^{-1}$. The main morphoagronomic characteristics of corn hybrids are described (Table 1).

Table 1. Main morphoagronomic characteristics of the evaluated corn hybrids. Mineiros-GO, UNIFIMES, Brazil, 2019.

\begin{tabular}{|c|c|c|c|c|c|}
\hline \multicolumn{2}{|c|}{ Nomenclature } & \multirow{2}{*}{ Cycle $^{1}$} & \multicolumn{3}{|c|}{ Grains } \\
\hline Commercial & Common & & $\mathrm{PMG}^{2}$ & $\mathrm{Cor}^{3}$ & Textura $^{4}$ \\
\hline 20A78 PW & $20 A 78$ & SE & $300-400$ & YE-OSH & SMHARD \\
\hline 2B533 PW & 2B587 & $\mathrm{E}$ & $300-400$ & YE-OSH & SMDENT \\
\hline 2B610 PW & 2B610 & SE & $300-400$ & YE-OSH & SMDENT \\
\hline 30F53 VYHR & $30 F 53$ & $E$ & 330 & YE-OSH & SMDENT \\
\hline CD 3770 PW & CD3770 & $E$ & $300-400$ & YE-OSH & SMHARD \\
\hline CD 384 PW & CD384 & E & $300-400$ & $\mathrm{OSH}$ & SMHARD \\
\hline DKB 310 PRO 3 & DKB310 & SME & 404 & YE-OSH & SMHARD \\
\hline LG 36701 VT PRO 2 & LG36701 & $E$ & $300-400$ & $\mathrm{OSH}$ & SMHARD \\
\hline LG 6030 VT PRO2 & LG6030 & $E$ & $300-400$ & $\mathrm{OSH}$ & SMDENT \\
\hline MG652 PW & MG652 & $E$ & $300-400$ & YE-OSH & SMHARD \\
\hline P3646 YHR & P3646 & $E$ & 345 & YE-OSH & SMHARD \\
\hline RB 9110 PRO & PB9110 & SE & $300-400$ & YE-OSH & SMHARD \\
\hline
\end{tabular}

${ }^{1}$ Cycle: SE-super early; E-early; SME-semi early. ${ }^{2} \mathrm{TGM}$ : Thousand grain mass (g). ${ }^{3} \mathrm{Grain}$ color: OSH-orangish; YE-yellow; OR-orange.

${ }^{4}$ Grain texture: SMDENT-semidentate; SMHARD-semihard. 
Prior to the installation of the experiment, soil collection and analysis was performed in the $0-20 \mathrm{~cm}$ surface layer and the following characteristics were observed: hydrogen potential 4.1 ; phosphorus $3 \mathrm{in} \mathrm{mg} \mathrm{dm}^{-3}$; potassium 0.6 , calcium 5 , magnesium 3 , aluminum 4 , potential acidity 29 , sum of bases 8.6 , cation exchange capacity 37.6 and base saturation 22.94 in mmolc dm${ }^{-3}$; clay 80 , silt 30 and sand $890 \mathrm{in} \mathrm{g} \mathrm{dm}^{-3}$. The analyzes were performed at the UNIFIMES Soil Chemistry and Fertility Laboratory, according to the methodology of (Embrapa 2009).

The tillage was performed in the conventional system by plowing with harrow and harrowing with grader (Ferreira et al. 2019b). Sowing was performed simultaneously in the furrow, and the distribution of the grains by hand. Conventional planting fertilization was carried out on February 17, 2017, using the NPK mineral of formula 8$25-15$ with a dose of $480 \mathrm{~kg} \mathrm{ha}^{-1}$.

During the execution of the experiment, BT Control $\AA^{\circ}$ was applied on April 17, 2017, Connect ${ }^{\circledR}$ on April 29, 2017, in addition to the application of Roundup Original $D I \circledast$ on March 04, 2017 and the fertilizer Freefós $\AA$, in November 03, 2017. For these, a cone-type 2.0 bar constant pressure (CO2) costal spray was used, applying a spray volume of $335 \mathrm{~L} \mathrm{ha}^{-1}$ during the warm hours of the day, with an average ambient temperature of $25{ }^{\circ} \mathrm{C}$, relative humidity of the air above $60 \%$ and winds below $5 \mathrm{~km} \mathrm{~h}^{-1}$.

At the end of the experiment, there were evaluated: plant height $(\mathrm{PH})$ in $\mathrm{m}$, ear insertion height $(\mathrm{EIH})$ in $\mathrm{m}$, stem diameter (SDI) in cm, leaf area index (LAI) in $\mathrm{cm}^{2}$ plant ${ }^{-1}$, strawless ear diameter (SED) in $\mathrm{cm}$, strawless ear length (SEL) in $\mathrm{cm}$, ear diameter with straw (EDS) in $\mathrm{cm}$, ear length with straw (ELS) in $\mathrm{cm}$, number of rows per ear (NRE) in units, number of grains per row (NGR) in units, number of grains per ear (NGE) in units, thousand grain mass (TGM) in g, and yield (YI) sc ha-1 of corn hybrids (Benincasa 2004).

Data were submitted to the assumptions of the statistical model, verifying the normality and homogeneity of the residual variances, as well as the additivity of the model. Afterwards, the analysis of variance was performed in order to identify the interaction between corn hybrids in the absence and presence of $A$. brasilensis. When verifying significant interaction, they were broken down to the simple and main effects through the Scott-Knott test of means at $5 \%$ probability.

Subsequently, the variables dismembered in the presence and absence of $A$. brasilensis were subjected to Pearson's linear correlation in order to understand the association tendency, and its significance was based on $5 \%$ probability by the $t$ test. Following, the path analysis was performed from the phenotypic correlation matrix, considering $\mathrm{YI}$ as the dependent variable and $\mathrm{PH}$, SDI, LAI, NGE and TGM as explanatory. Identifying the presence of high multicollinearity among the data, the path analysis was performed under multicollinearity, with subsequent adjustment of the $\mathrm{k}$ factor to the diagonal elements of the correlation matrix.

After, genetic dissimilarity by the Mahalanobis algorithm was performed, where the residual matrix was weighted, the distances dendrogram was constructed through the UPGMA cluster, and the biplot canonical variables method was used to visualize the general variability of the experiment and multivariate trends. The analyzes were performed in the interface Rbio and R (Bhering 2017), in addition to Software Genes (Cruz 2016).

\section{RESULTS AND DISCUSSION}

The summary analysis of variance with the mean square MS and significance by the $\mathrm{F}$ test revealed significant interaction between hybrid $\times A$. brasilense in the variables plant height $\mathrm{PH}$, ear insertion height $\mathrm{EIH}$, leaf area index LAI, strawless ear diameter SED, number of rows per ear NRE, number of grains per row NGR, number of grains per ear NGE, thousand grain mass TGM and yield $\mathrm{YI}(\mathrm{p}<0.01)$ (Table 2), corroborating Lana et al. (2012), Dartora et al. (2013), Müller et al. (2016), Arantes et al. (2017), Brito (2019), Ferreira et al. (2019a).

For $\mathrm{PH}$ and $\mathrm{EIH}$, it was observed that corn hybrids 20A78 and MG652 when evaluated in relation to the others in the absence and presence of $A$. brasilense were the ones that differed positively from the others, reaching the averages of 1.91 and $101.30 \mathrm{~cm}$ respectively (Table 3). Costa et al. (2015) and Kopper et al. (2017) found similar results, showing that the use of bacteria promoted higher $\mathrm{PH}$ and ElH. Kappes et al. (2013) observed higher $\mathrm{PH}$ and EIH with the presence of $A$. brasilense, relating this fact to the growth-promoting substances produced by the bacteria, compared with Bashan and Holguin (1997) who state that this stimulus is due to the production of indoleacetic acid, being an important factor for plant growth. For Possamai et al. (2001), plants with high PH and EIH have advantages in harvesting, influencing grain losses and purity in mechanized harvesting.

Hybrids 20A78 and 2B610 had higher LAI when A. brasilense was present, with an average of $11,203.43 \mathrm{~cm}^{2}$ plant $^{-1}$ (Table 3). Corroborating Arantes et al. (2017), who in turn reported that the increase of the LAl with the presence of $A$. brasilense represents an important factor for the capture of light energy, which will be converted into photoassimilates and translocated for grain filling. The increase in LAI may be associated with the production of phytohormones by bacteria such as auxin, gibberillin and cytokine (Dartora et al. 2013). When analyzing the SED 
variable, three hybrids stood out: CD3770 $(5.97 \mathrm{~cm})$, LG36701 $(5.25 \mathrm{~cm})$ and PB9110 $(5.53 \mathrm{~cm})$, reaching higher averages in the presence of $A$. brasilense (Table 3).

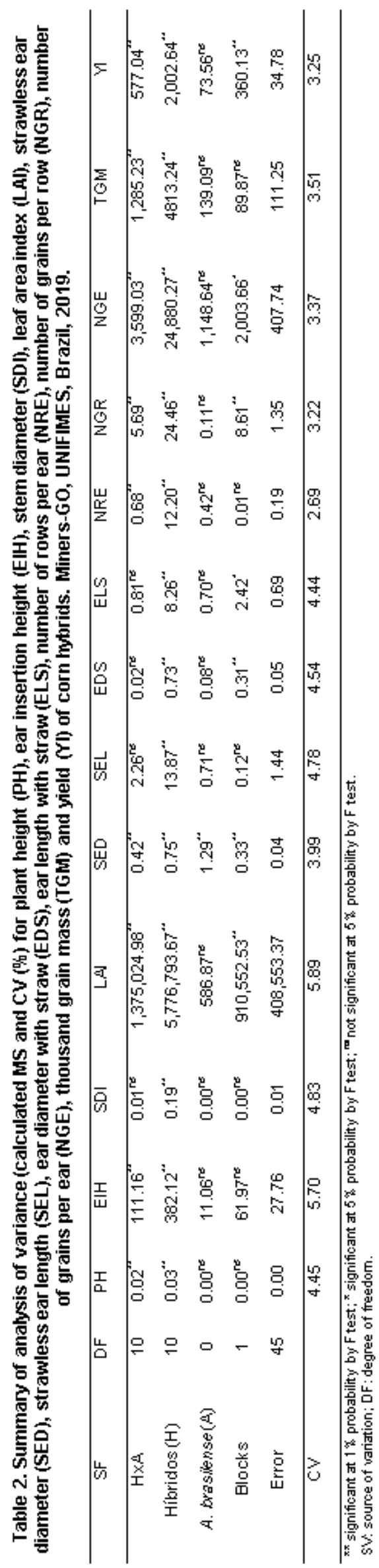

The stem diameter SDI was not influenced by $A$. brasilense. The hybrid LG6030 was superior in both situations with an average of 2.92 and 2.69 $\mathrm{cm}$, in this order (Table 4). Distinct results with elevation to SDI using $A$. brasilense in corn were reported by Costa et al. (2015) and Brito (2019), besides the increase in leaf dry mass, root volume, and the nitrogen, phosphorus and potassium contents.

The hybrid DKB310 presented the largest strawless ear length (SEL), ear diameter with straw (EDS) and ear length with straw (ELS), among the other hybrids both in the absence and presence of $A$. brasilensis, with averages of 27.26, 5.49 and 21.45, respectively (Table 4). According to Basi (2013), who evaluated different modes of inoculation with $A$. brasilense in corn, there was no difference for treatments without inoculation, seed inoculation and seeding inoculation at furrow. For Taiz et al. (2017) factors such as light (intensity, quality and duration), water (soil availability and moisture), carbon dioxide, oxygen, soil nutrient content and availability, temperature and toxins (inert ingredients, heavy metals and salinity) may affect plant growth and development.

Based on the results presented in Table 5, it was observed that in the variables NRE, NGR and NGE the hybrid 2B587 when evaluated in the absence and presence of $A$. brasilense stood out with higher averages in the presence of treatment with averages $17.40,39.25$ and 683.37 units. respectively. Matos et al. (2017), when evaluating the effect of $N$ doses and inoculation with $A$. brasilense in corn, did not observe alteration in NRE. According to Valderrama et al. (2011), NRE is a genetic trait of each genotype, thus having no significant effect. Regarding how grain size and other ear characteristics are established by genes located in many chromosomes, it is therefore subject to the choice of hybrid (Lopes et al. 2017).

In Table 5, it was analyzed that in the TGM variable the hybrids that positively differentiated in the presence of $A$. brasilense were 20A78 (308.02 g), CD3770 (320.44 g) and MG652 (383.62 g). Cunha et al. (2016) report that the results obtained regarding the use of $A$. brasilense inoculation may vary depending on the hybrid used, but that the higher $\mathrm{N}$ absorption efficiency promoted by bacterial inoculation positively influences metabolism, resulting in plants with higher photosynthetic performance. Bacteria of the genus Azospirillum can be inoculated in plants of agronomic interest, stimulating their growth by multiple mechanisms, including phytohormone synthesis, improved nitrogen nutrition, stress mitigation and biological control of pathogenic microbiota (Bashan and Bashan 2010, Quadros et al. 2014).

Regarding the $\mathrm{YI}$ variable, the hybrid DKB310 when evaluated in the absence and presence of $A$. brasilense was the one that obtained the highest average in the presence with $231.39 \mathrm{sc} \mathrm{ha}^{-1}$ (Table 5). The increase in productivity was also evidenced by Cunha et al. (2014), Costa et al. (2015), Morais et al. (2016), Müller et al. (2016) and Caprio (2017), who obtained a $2 \%$ increase in productivity when using A. brasilense applied in the sowing furrow, and Lana et al. (2012) confirmed the beneficial effects by observing increases of 7 to $15 \%$ in corn yield due to inoculation with $A$. brasilense. On the other hand, for Brito (2019), inoculation methods with $A$. brasilense had little influence on morphometric and nutritional parameters of corn development, and did not influence yield. 
Table 3. Breakdown of corn hybrids within the absence and presence of $A$. brasilense for plant height (PH), ear insertion height (EIH), leaf area index (LAI) and strawless ear diameter (SED). Mineiros-GO. UNIFIMES. Brazil. 2019.

\begin{tabular}{|c|c|c|c|c|c|c|c|c|}
\hline \multirow{3}{*}{ Hybrids } & \multicolumn{2}{|c|}{$\mathrm{PH}$} & \multicolumn{2}{|c|}{ ElH } & \multicolumn{2}{|c|}{ LAl } & \multicolumn{2}{|c|}{ SED } \\
\hline & Absence & Presence & Absence & Presence & Absence & Presence & Absence & Presence \\
\hline & \multicolumn{2}{|c|}{--------m-------- } & \multicolumn{2}{|c|}{--------cm------- } & \multicolumn{2}{|c|}{--------cm² plant ${ }^{-1}$} & \multicolumn{2}{|c|}{--------cm-------- } \\
\hline $20 A 78$ & $1.71 \mathrm{Bb}$ & $1.95 \mathrm{aA}$ & $91.65 \mathrm{cB}$ & $107.00 \mathrm{aA}$ & $9,492.12 \mathrm{~dB}$ & $10,637.33 \mathrm{bA}$ & $5.65 \mathrm{bA}$ & $5.92 \mathrm{aA}$ \\
\hline 2B587 & $1.84 \mathrm{Ba}$ & $1.85 \mathrm{aA}$ & $83.55 \mathrm{dA}$ & $76.60 \mathrm{dA}$ & $10,796.06 \mathrm{cA}$ & $10,651.22 \mathrm{bA}$ & $5.84 \mathrm{bA}$ & $6.04 \mathrm{aA}$ \\
\hline 2B610 & $1.82 \mathrm{Ba}$ & $1.96 \mathrm{aA}$ & $97.75 \mathrm{bA}$ & $99.00 \mathrm{aA}$ & $10,444.35 \mathrm{cB}$ & $11,769.53 \mathrm{aA}$ & $5.57 \mathrm{bA}$ & $5.70 \mathrm{aA}$ \\
\hline $30 F 53$ & $1.99 \mathrm{Aa}$ & $1.98 \mathrm{aA}$ & $99.06 \mathrm{bA}$ & $100.30 \mathrm{aA}$ & $11,637.58 \mathrm{bA}$ & $11,759.75 \mathrm{aA}$ & $5.24 \mathrm{cA}$ & $5.30 \mathrm{bA}$ \\
\hline CD3770 & $1.90 \mathrm{Aa}$ & $1.91 \mathrm{aA}$ & $94.60 \mathrm{bA}$ & $87.90 \mathrm{cA}$ & $9,884.06 \mathrm{cA}$ & $10,768.14 \mathrm{bA}$ & $4.16 \mathrm{~dB}$ & $5.97 \mathrm{aA}$ \\
\hline CD384 & $1.89 \mathrm{Aa}$ & $1.99 \mathrm{aA}$ & $82.05 \mathrm{~dB}$ & $91.45 \mathrm{bA}$ & $11,442.61 \mathrm{bA}$ & $10,418.54 \mathrm{bA}$ & $6.06 \mathrm{aA}$ & $5.74 \mathrm{aA}$ \\
\hline DKB310 & $1.99 \mathrm{Aa}$ & $1.93 \mathrm{aA}$ & $109.70 \mathrm{aA}$ & $102.90 \mathrm{aA}$ & $13,547.32 \mathrm{aA}$ & $12,516.93 \mathrm{aA}$ & $6.02 \mathrm{aA}$ & $6.02 \mathrm{aA}$ \\
\hline LG36701 & $1.91 \mathrm{Aa}$ & $1.97 \mathrm{aA}$ & $93.43 \mathrm{cA}$ & $91.96 \mathrm{bA}$ & $12,041.11 \mathrm{bA}$ & $11,615.66 \mathrm{aA}$ & $5.05 \mathrm{cA}$ & $5.24 \mathrm{bA}$ \\
\hline LG6030 & $1.94 \mathrm{Aa}$ & $1.75 \mathrm{bB}$ & $101.50 \mathrm{bA}$ & $93.82 \mathrm{bA}$ & $10,154.82 \mathrm{cA}$ & $9,283.14 \mathrm{bA}$ & $4.87 \mathrm{cB}$ & $5.25 \mathrm{bA}$ \\
\hline MG652 & $1.71 \mathrm{Bb}$ & $1.88 \mathrm{aA}$ & $86.20 \mathrm{~dB}$ & $95.60 \mathrm{bA}$ & $11,484.38 \mathrm{bA}$ & $10,055.48 \mathrm{bB}$ & $5.79 \mathrm{bA}$ & $5.63 \mathrm{aA}$ \\
\hline P3646 & $1.76 \mathrm{Ba}$ & $1.70 \mathrm{bA}$ & $90.30 \mathrm{cA}$ & $76.10 \mathrm{~dB}$ & $10,314.88 \mathrm{cA}$ & $10,715.35 \mathrm{bA}$ & $5.60 \mathrm{bA}$ & $5.89 \mathrm{aA}$ \\
\hline PB9110 & $1.94 \mathrm{Aa}$ & $1.80 \mathrm{bB}$ & $85.10 \mathrm{dA}$ & $82.85 \mathrm{cA}$ & $9029.68 \mathrm{dA}$ & $10,006.39 \mathrm{bA}$ & $5.14 \mathrm{Cb}$ & $5.53 \mathrm{bA}$ \\
\hline
\end{tabular}

Averages followed by the same lowercase letter in the column by the Scott Knott test. and uppercase in the row by the Tukey test. do not differ from each other at $5 \%$ probability.

Table 4. Average for the main effects of corn hybrids within the absence and presence of $A$. brasilense for stem diameter (SDI), strawless ear length (SEL), ear diameter with straw (EDS) and ear length with straw (ELS). Mineiros-GO. UNIFIMES. Brazil. 2019.

\begin{tabular}{|c|c|c|c|c|c|c|c|c|}
\hline \multirow[b]{2}{*}{ Hybrids } & \multicolumn{2}{|c|}{ SDI } & \multicolumn{2}{|c|}{ SEL } & \multicolumn{2}{|c|}{ EDS } & \multicolumn{2}{|c|}{ ELS } \\
\hline & Absence & Presence & Absence & Presence & Absence & Presence & Absence & Presence \\
\hline $20 A 78$ & $2.18 \mathrm{c}$ & $2.37 b$ & $25.35 b$ & $23.10 \mathrm{~b}$ & $5.34 \mathrm{a}$ & $5.53 \mathrm{a}$ & $18.10 \mathrm{c}$ & $17.40 \mathrm{~d}$ \\
\hline 2B587 & $2.48 \mathrm{~b}$ & $2.55 \mathrm{a}$ & $23.35 c$ & $24.10 \mathrm{~b}$ & $5.43 \mathrm{a}$ & $5.53 \mathrm{a}$ & $17.30 \mathrm{c}$ & $17.90 \mathrm{~d}$ \\
\hline 2B610 & $2.37 \mathrm{c}$ & $2.41 b$ & $25.75 b$ & $27.00 \mathrm{a}$ & $5.25 \mathrm{a}$ & $5.38 \mathrm{a}$ & $18.55 \mathrm{c}$ & $18.80 \mathrm{c}$ \\
\hline 30F53 & $2.52 \mathrm{~b}$ & $2.50 \mathrm{a}$ & $25.46 \mathrm{~b}$ & $26.50 \mathrm{a}$ & $4.62 \mathrm{c}$ & $4.67 \mathrm{~b}$ & $19.10 b$ & $18.33 \mathrm{c}$ \\
\hline CD3770 & $2.27 \mathrm{c}$ & $2.21 \mathrm{~b}$ & $24.10 \mathrm{c}$ & $24.70 \mathrm{~b}$ & $5.50 \mathrm{a}$ & $5.49 \mathrm{a}$ & $17.00 \mathrm{c}$ & $18.50 \mathrm{c}$ \\
\hline CD384 & $2.41 \mathrm{c}$ & $2.23 \mathrm{~b}$ & $22.75 \mathrm{c}$ & $24.25 b$ & $5.64 \mathrm{a}$ & $5.42 \mathrm{a}$ & $17.75 \mathrm{c}$ & $17.00 \mathrm{~d}$ \\
\hline DKB310 & $2.57 \mathrm{~b}$ & $2.54 \mathrm{a}$ & $27.80 \mathrm{a}$ & $26.75 \mathrm{a}$ & $5.46 \mathrm{a}$ & $5.53 \mathrm{a}$ & $21.00 \mathrm{a}$ & $21.90 \mathrm{a}$ \\
\hline LG36701 & $2.56 \mathrm{~b}$ & $2.56 \mathrm{a}$ & $25.73 b$ & $26.25 \mathrm{a}$ & $4.42 \mathrm{c}$ & $4.51 \mathrm{~b}$ & $18.40 \mathrm{c}$ & $18.83 \mathrm{c}$ \\
\hline LG6030 & $2.92 \mathrm{a}$ & $2.69 \mathrm{a}$ & $28.31 \mathrm{a}$ & $27.40 \mathrm{a}$ & $4.94 \mathrm{~b}$ & $5.05 \mathrm{a}$ & $19.91 \mathrm{~b}$ & $19.41 \mathrm{c}$ \\
\hline MG652 & $2.20 \mathrm{c}$ & $2.23 \mathrm{~b}$ & $24.20 \mathrm{c}$ & $24.05 b$ & $5.26 \mathrm{a}$ & $5.24 \mathrm{a}$ & $19.45 b$ & $19.20 \mathrm{c}$ \\
\hline P3646 & $2.24 \mathrm{c}$ & $2.32 \mathrm{~b}$ & $23.30 \mathrm{c}$ & $25.15 b$ & $5.24 \mathrm{a}$ & $5.23 \mathrm{a}$ & $19.10 \mathrm{~b}$ & $20.25 b$ \\
\hline PB9110 & $2.26 \mathrm{c}$ & $2.26 \mathrm{~b}$ & $23.90 \mathrm{c}$ & $23.15 b$ & $4.85 \mathrm{~b}$ & $5.20 \mathrm{a}$ & $18.00 \mathrm{c}$ & $18.00 \mathrm{~d}$ \\
\hline
\end{tabular}

Averages followed by the same lowercase letter in the column and uppercase in the row do not differ from each other by Scott Knott's test at $5 \%$ probability.

The correlation network with Pearson's correlation coefficient revealed 9 positive and significant correlations, 3 in the absence and 6 in the presence. The SELXEIH, EDSXNRE, and NREXNGE pairs in the absence, and presence reported in the EIHxPH, SEDxEDS, SEDxNRE, NRExNGE, NGExNGR, and TGMxYI pairs (Figure 1). Silva et al. (2015) state that multivariate analysis techniques are efficient to verify similarities or differences in yield variability based on chemical and physical soil attributes in the studied area.

The variables that most contributed to the increase in YI directly and in decreasing order were TGM, NGE, LAI, SDI and $\mathrm{PH}$, both in the presence and absence of $A$. brasilensis (Table 6). In addition to being the largest contributor to the increase in YI, TGM was also the variable that most indirectly influenced variables such as SDI $(-0.11)$, LAI $(0.23)$ and NGE $(-0.31)$ in the absence, as well as in the latter with presence of $A$. brasilensis, as it was also negatively influenced by NGE in both situations with the bacteria in question (Table 6).

Biologically it can be reported that corn hybrid plants in the absence of A. brasilensis with high SDI, presenting robust LAI, ears with high NGE and grain at $13 \%$ moisture with high biomass accumulation, provide high levels of 
YI. The same can be observed for hybrids with the presence of bacteria plus the characteristic of high PH plants (Table 6).

When analyzing the dissimilarity dendrogram between maize hybrids in the absence and presence of $A$. brasilensis, it can be noted that in the absence, two Clusters were formed, highlighting one formed by the hybrid DKB310 and the other hybrids with similar characteristics being in the second cluster (Figure 2A). And in the presence, three Clusters were formed, the first formed by the hybrids DKB310, LG36701, 2B610 and 30F53, the second highlighting the hybrid LG6030 and third formed by the other hybrids (Figure 2B). Nardino et al. (2017) testing genetic dissimilarity among 25 corn genotypes in five growing environments in southern Brazil, observed the formation of nine distinct clusters. Silva et al. (2016) estimating genetic divergence between half-siblings progenies through hierarchical methods observed the formation of 11 clusters, as well as, Alves et al. (2015), which accounted for the formation of four clusters, based on studies with genetic divergence between corn genotypes.

Table 5. Breakdown of corn hybrids within the absence and presence of $A$. brasilense for number of rows per ear (NRE), number of grains per row (NGR), number of grains per ear (NGE), thousand grain mass (TGM) and yield (YI). Mineiros-GO. UNIFIMES. Brazil. 2019.

\begin{tabular}{|c|c|c|c|c|c|c|c|c|c|c|}
\hline \multirow{3}{*}{ Hybrids } & \multicolumn{2}{|c|}{ NGE } & \multicolumn{2}{|c|}{ NGR } & \multicolumn{2}{|c|}{ NGE } & \multicolumn{2}{|c|}{ TGM } & \multicolumn{2}{|c|}{$\mathrm{YI}$} \\
\hline & Absence & Presence & Absence & Presence & Absence & Presence & Absence & Presence & Absence & Presence \\
\hline & \multicolumn{6}{|c|}{----------------------------unit---------------------------- } & \multicolumn{2}{|c|}{ 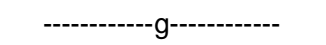 } & \multicolumn{2}{|c|}{--------sc ha-1------- } \\
\hline $20 \mathrm{~A} 78$ & $18.40 \mathrm{bA}$ & $17.40 \mathrm{bB}$ & $35.30 \mathrm{cA}$ & $34.80 \mathrm{bA}$ & $649.46 \mathrm{bA}$ & $605.52 \mathrm{bB}$ & $272.20 \mathrm{~dB}$ & $308.02 \mathrm{cA}$ & $176.73 \mathrm{cB}$ & $186.51 \mathrm{cA}$ \\
\hline 2B587 & $16.20 \mathrm{~dB}$ & $17.40 \mathrm{bA}$ & $34.60 \mathrm{cB}$ & $39.25 \mathrm{aA}$ & $560.33 \mathrm{~dB}$ & $683.37 \mathrm{aA}$ & $310.94 \mathrm{cA}$ & $297.24 \mathrm{cA}$ & $174.25 \mathrm{cB}$ & $202.88 \mathrm{bA}$ \\
\hline 2B610 & $16.70 \mathrm{~dB}$ & $17.80 \mathrm{bA}$ & $36.35 \mathrm{bA}$ & $37.70 \mathrm{aA}$ & $605.99 \mathrm{cB}$ & $671.06 \mathrm{aA}$ & $288.90 \mathrm{cA}$ & $284.57 \mathrm{cA}$ & $175.11 \mathrm{cB}$ & $190.97 \mathrm{cA}$ \\
\hline 30F53 & $14.86 \mathrm{fA}$ & $15.31 \mathrm{dA}$ & $37.56 \mathrm{bA}$ & $36.25 \mathrm{bA}$ & $558.45 \mathrm{dA}$ & $555.32 \mathrm{cA}$ & $263.83 \mathrm{dA}$ & $265.35 \mathrm{dA}$ & $146.57 \mathrm{dA}$ & $147.42 \mathrm{fA}$ \\
\hline CD3770 & $17.20 \mathrm{cA}$ & $16.50 \mathrm{cA}$ & $32.70 \mathrm{cA}$ & $33.00 \mathrm{cA}$ & $562.44 \mathrm{dA}$ & $544.50 \mathrm{cA}$ & $296.49 \mathrm{cB}$ & $320.44 \mathrm{bA}$ & $166.76 \mathrm{cA}$ & $174.48 \mathrm{dA}$ \\
\hline CD384 & $19.20 \mathrm{aA}$ & $19.40 \mathrm{aA}$ & $36.52 \mathrm{bA}$ & $35.45 \mathrm{bA}$ & $701.54 \mathrm{aA}$ & $687.23 \mathrm{aA}$ & $276.98 \mathrm{dA}$ & $270.53 \mathrm{dA}$ & $194.22 \mathrm{bA}$ & $186.08 \mathrm{cA}$ \\
\hline DKB310 & $17.40 \mathrm{cA}$ & $17.70 \mathrm{bA}$ & $37.40 \mathrm{bB}$ & $39.97 \mathrm{aA}$ & $650.01 \mathrm{bB}$ & $707.64 \mathrm{aA}$ & $324.12 \mathrm{bA}$ & $326.78 \mathrm{bA}$ & $210.69 \mathrm{aB}$ & $231.39 \mathrm{aA}$ \\
\hline LG36701 & $14.10 \mathrm{gA}$ & 13.62 eA & $34.44 \mathrm{cA}$ & $32.98 \mathrm{cA}$ & $485.46 \mathrm{eA}$ & $449.28 \mathrm{~dB}$ & $309.23 \mathrm{cA}$ & $289.74 \mathrm{cB}$ & $171.79 \mathrm{cA}$ & $160.97 \mathrm{eB}$ \\
\hline LG6030 & $15.85 \mathrm{eA}$ & $15.91 \mathrm{dA}$ & $40.50 \mathrm{aA}$ & $39.09 \mathrm{aA}$ & $641.75 \mathrm{bA}$ & $621.81 \mathrm{bA}$ & $302.28 \mathrm{cA}$ & $264.58 \mathrm{~dB}$ & $193.97 \mathrm{bA}$ & $164.58 \mathrm{eB}$ \\
\hline MG652 & $15.50 \mathrm{eA}$ & $15.20 \mathrm{dA}$ & $35.25 \mathrm{cA}$ & $35.85 \mathrm{bA}$ & $546.94 \mathrm{dA}$ & $544.91 \mathrm{cA}$ & $349.74 \mathrm{aB}$ & $383.62 \mathrm{aA}$ & $190.36 \mathrm{bB}$ & $208.94 \mathrm{bA}$ \\
\hline P3646 & $16.00 \mathrm{eA}$ & $16.60 \mathrm{cA}$ & $34.50 \mathrm{cA}$ & $33.50 \mathrm{cA}$ & $552.00 \mathrm{dA}$ & $556.08 \mathrm{cA}$ & $359.94 \mathrm{aA}$ & $295.00 \mathrm{cB}$ & $198.69 \mathrm{bA}$ & $163.97 \mathrm{eB}$ \\
\hline PB9110 & $16.55 \mathrm{dA}$ & $16.95 \mathrm{cA}$ & $37.45 \mathrm{bA}$ & $35.70 \mathrm{bA}$ & $620.06 \mathrm{cA}$ & $603.58 \mathrm{bA}$ & $272.19 \mathrm{dA}$ & $287.61 \mathrm{cA}$ & $168.45 \mathrm{cA}$ & $173.65 \mathrm{dA}$ \\
\hline
\end{tabular}

Averages followed by the same lowercase letter in the column by the Scott Knott test. and uppercase in the row by the Tukey test. do not differ from each other at $5 \%$ probability.
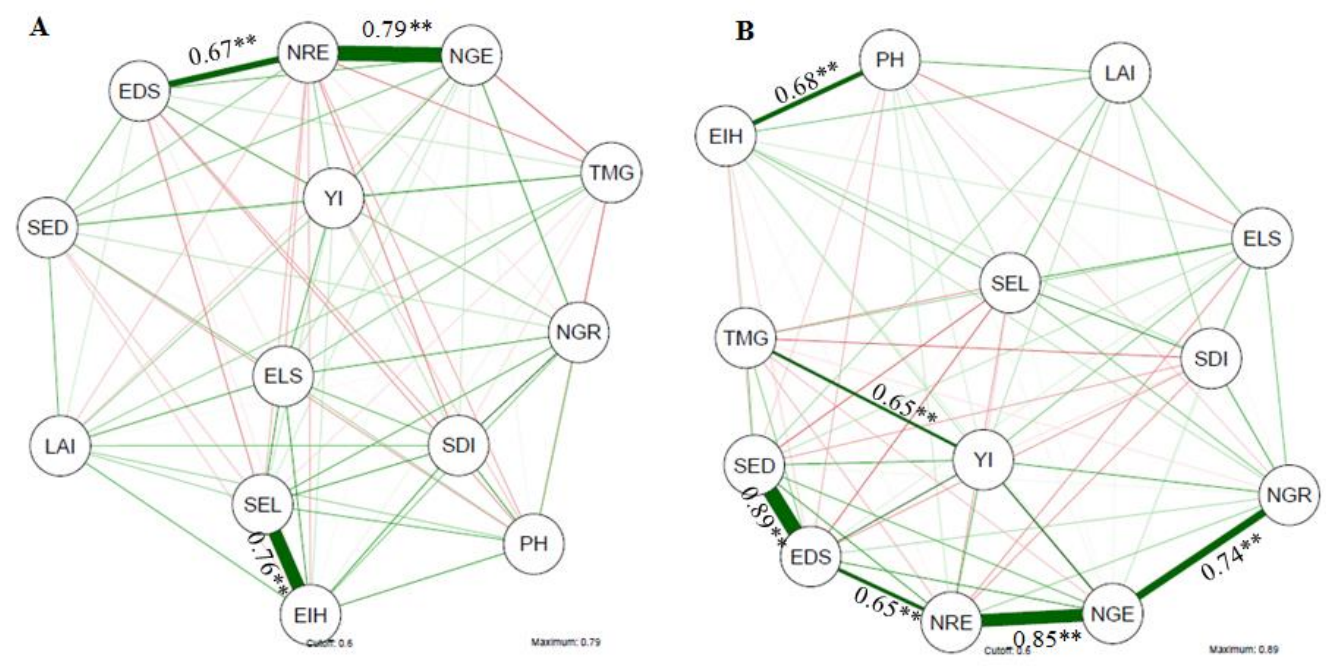

Figure 1. Network of linear correlations for characters of corn hybrids with absence (A) and presence (B) of A. brasilensis. Mineiros-GO. UNIFIMES. Brazil. 2019.

Significance: * $5 \%$ probability; ${ }^{* *} 1 \%$ probability; ${ }^{\text {ns}}$ : not significant by t-test.

Variables: plant height (PH), ear insertion height (EIH), stem diameter (SDI), leaf area index (LAI), strawless ear diameter (SED), strawless ear length (SEL), ear diameter with straw (EDS), ear length with straw (ELS), number of rows per ear (NRE), number of grains per row (NGR), number of grains per ear (NGE), thousand grain mass (TGM) and yield (YI). 
Table 6. Estimates of direct and indirect effects on phenotypic path analysis of explanatory characters plant height

(PH). stem diameter (SDI). leaf area index (LAI). number of grains per ear (NGE). thousand grain mass (TGM). on YI yield of corn hybrids in the absence (ABS) and presence (PRE) of A. brasilensis. Mineiros-GO. UNIFIMES. Brazil. 2019.

\begin{tabular}{|c|c|c|c|c|c|c|c|c|c|c|c|}
\hline \multirow{2}{*}{ Effect } & \multirow{2}{*}{ Variables } & ABS & PRE & ABS & PRE & $A B S$ & PRE & ABS & PRE & ABS & PRE \\
\hline & & \multicolumn{2}{|c|}{$\mathrm{PH}$} & \multicolumn{2}{|c|}{ SDI } & \multicolumn{2}{|c|}{ LAI } & \multicolumn{2}{|c|}{ NGE } & \multicolumn{2}{|c|}{ TGM } \\
\hline Direct effect on & $\mathrm{YI}$ & -0.05 & 0.10 & 0.11 & 0.11 & 0.14 & 0.11 & 0.66 & 0.64 & 0.76 & 0.71 \\
\hline Indirect effect via & $\mathrm{PH}$ & & & -0.03 & 0.00 & -0.02 & 0.06 & 0.00 & 0.00 & 0.01 & 0.00 \\
\hline Indirect effect via & SDI & 0.07 & 0.00 & & & 0.03 & 0.02 & 0.01 & 0.01 & -0.01 & -0.05 \\
\hline Indirect effect via & LAI & 0.06 & 0.06 & 0.05 & 0.02 & & & -0.01 & 0.01 & 0.04 & 0.00 \\
\hline Indirect effect via & NGE & 0.01 & 0.01 & 0.07 & 0.05 & -0.06 & 0.04 & & & -0.27 & -0.10 \\
\hline Indirect effect via & TGM & -0.19 & -0.02 & -0.11 & -0.33 & 0.23 & 0.00 & -0.31 & -0.11 & & \\
\hline TOTAL & & -0.10 & 0.12 & 0.10 & -0.14 & 0.34 & 0.22 & 0.41 & 0.61 & 0.62 & 0.63 \\
\hline \multicolumn{12}{|c|}{ 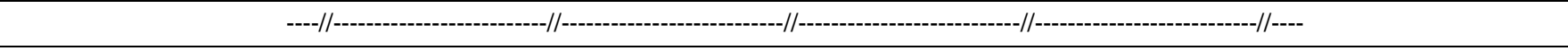 } \\
\hline \multicolumn{6}{|c|}{ Determination coefficient } & \multicolumn{4}{|c|}{0.81} & \multirow{3}{*}{ PRE } & 0.84 \\
\hline \multicolumn{6}{|l|}{$\mathrm{K}$ value used in analysis } & \multirow{2}{*}{\multicolumn{2}{|c|}{ ABS }} & \multirow{2}{*}{\multicolumn{2}{|c|}{$\begin{array}{l}0.11 \\
0.43\end{array}$}} & & 0.11 \\
\hline \multicolumn{6}{|c|}{ Effect of residual variable } & & & & & & 0.43 \\
\hline \multicolumn{6}{|c|}{ Determinant of the correlation matrix between explanatory variables } & & & \multicolumn{2}{|l|}{0.46} & & 0.64 \\
\hline
\end{tabular}
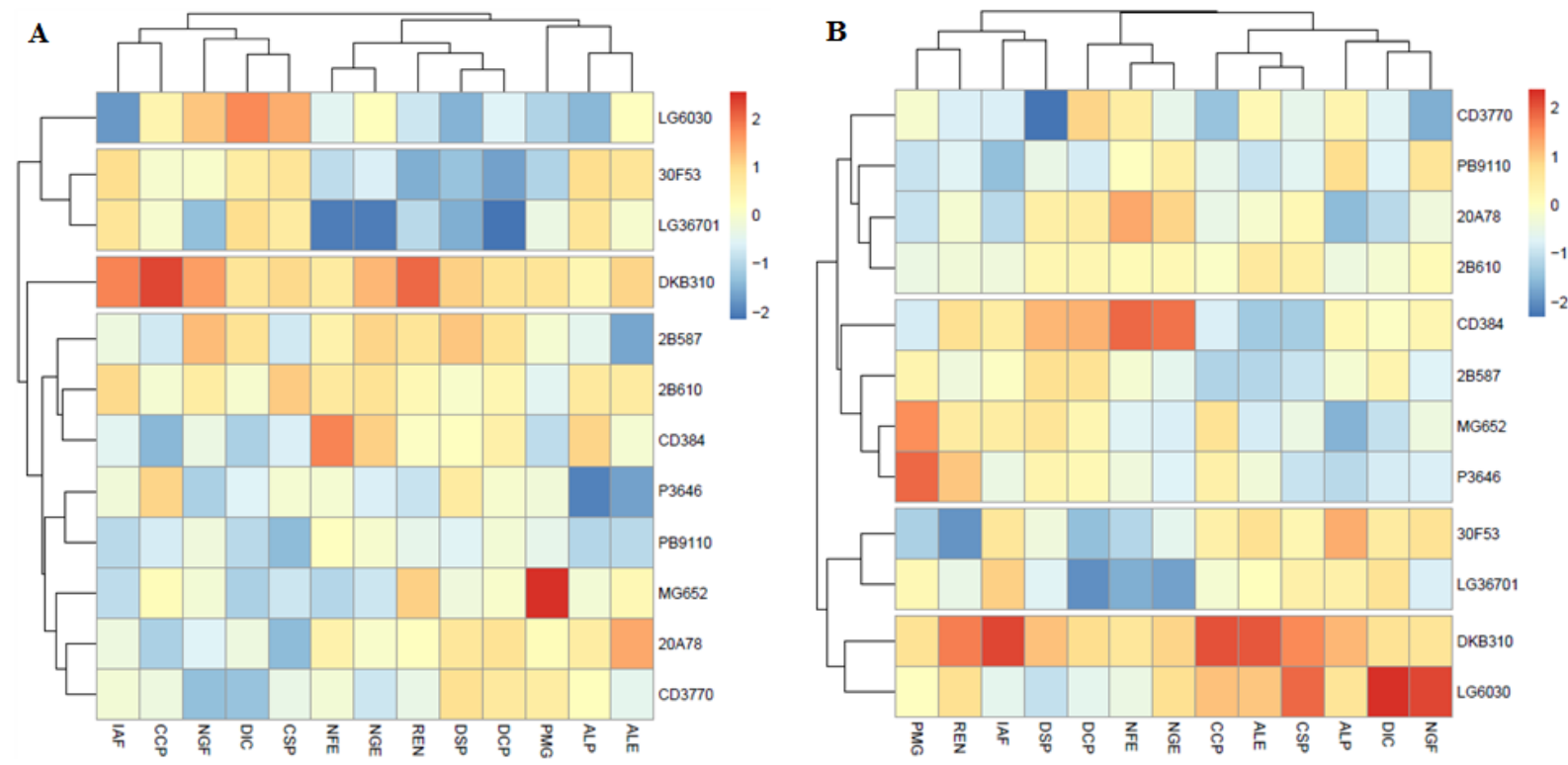

Figure 2. Dendrogram representing the dissimilarity among corn hybrids. obtained by UPGMA clustering method. using the generalized Mahalanobis distance. in the absence (A) and presence (B) of $A$. brasilensis. Mineiros-GO. UNIFIMES. Brazil. 2019.

Variables: plant height (PH), ear insertion height (EIH), stem diameter (SDI), leaf area index (LAI), strawless ear diameter (SED), strawless ear length (SEL), ear diameter with straw (EDS), ear length with straw (ELS), number of rows per ear (NRE), number of grains per row (NGR), number of grains per ear (NGE), thousand grain mass (TGM) and yield (YI).

In the analysis of canonical variables (Figure $3 \mathrm{~A}$ ) it was found that it explained $89.4 \%$ of the total data variation, noting that the variables EDS, TGM and YI showed similarity of magnitude to each other in the hybrid DKB310. In (Figure 3B) responded with $98.3 \%$ of the total data variation, demonstrating that the SED and $\mathrm{YI}$ variables had similarity of magnitude in the 2B610 and 20A78 hybrids. Guimarães et al. (2014), analyzing the development of corn crop in different soil types, as a function of inoculation with A. brasilense and Herbaspirillum seropedicae, highlighted that inoculated plants showed higher development than those not inoculated in soils characterized by Eutroferric Oxisols, Dystroferric Ultisols and Eutropheric Ultisols.

The interactions between the factors were divided into simple and main effects, applying as univariate tools clustering test and averages, correlation network and Pearson correlation coefficients, where it was possible to observe the variability of hybrids and distinction in their variables with the presence of $A$. brasilense bacteria via seed. In the multivariate analyzes one can observe the direct effects of variables on grain yield, the hybrid grouping through the Cluster dendrogram, and their expressiveness on the variables in the canonical variables. 


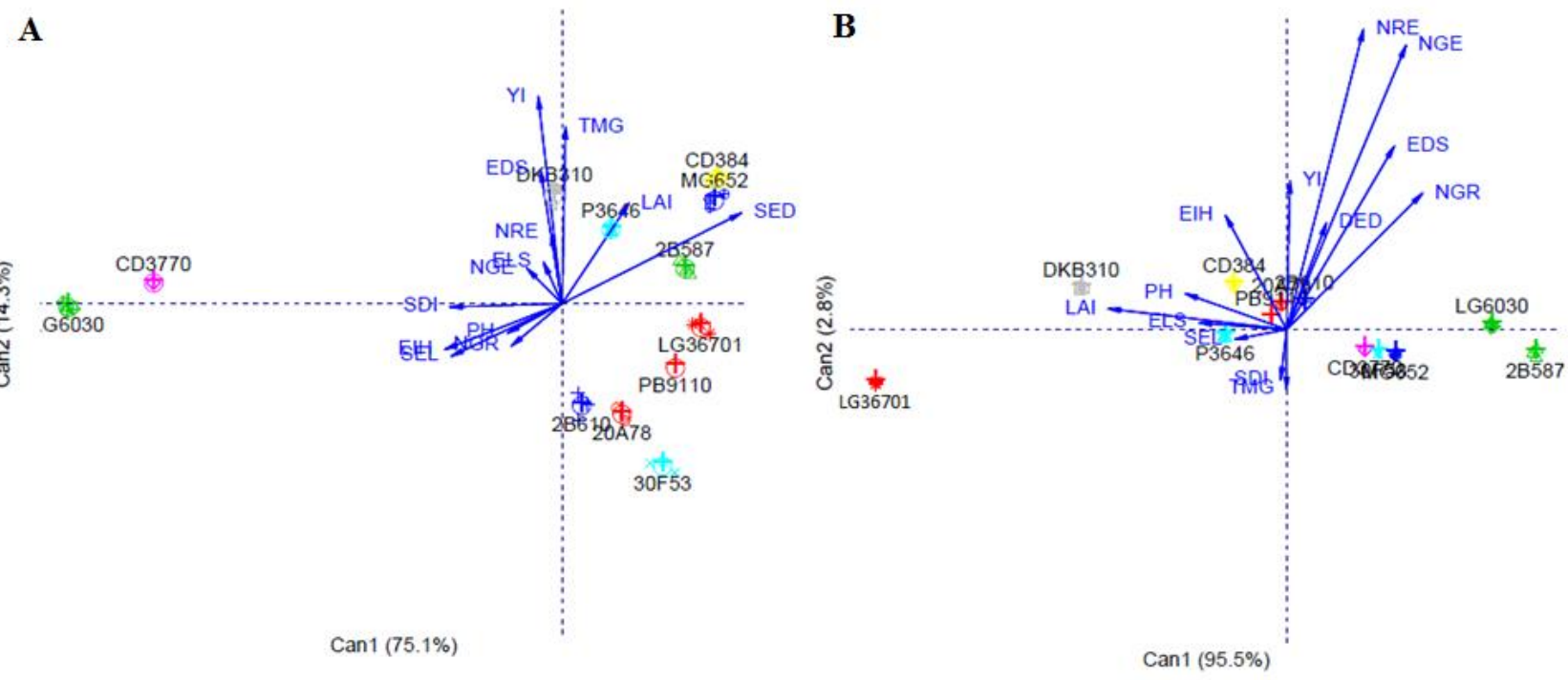

Figure 3. Analysis of canonical variables of characters of corn hybrids with absence (A) and presence (B) of A. brasilensis. Mineiros-GO. UNIFIMES. Brazil. 2019.

Variables: plant height (PH), ear insertion height (EIH), stem diameter (SDI), leaf area index (LAI), strawless ear diameter (SED), strawless ear length (SEL), ear diameter with straw (EDS), ear length with straw (ELS), number of rows per ear (NRE), number of grains per row (NGR), number of grains per ear (NGE), thousand grain mass (TGM) and yield (YI).

\section{References}

Alves BM et al. 2015. Divergência genética de milho transgênico em relação à produtividade de grãos e da qualidade nutricional. Ciência Rural Santa Maria 45:884-891.

Arantes ACC et al. 2018. Crescimento e desenvolvimento de milho orgânico inoculado com Azospirillum brasilense. Cadernos de Agroecologia 3:1(7p).

Bashan $Y$ et al 2010. How the plant growth-promoting bacterium Azospirillum promotes plant growth - a critical assessment. Advances in agronomy 108:77-136.

Bashan Y, Holguin G. 1997. Azospirillum-plant relationships: environmental and physiological advances (1990-1996). Canadian Journal of Microbiology 43:103-121.

Basi S. 2013 Associação de Azospirillum brasilense e de nitrogênio em cobertura na cultura de milho. 50 f. Dissertation (Master) - Cedeteg Faculty, Universidade Estadual do Centro-Oeste, Guarapuava.

Benincasa MMP. 2003. Análise de crescimento de plantas: noções básicas. Jaboticabal: FUNEP.

Bhering LL. 2017. Rbio: A tool for biometric and statistical analysis using the R platform. Crop Breeding and Applied Biotechnology 17:187-190.

Brito TS. 2019. Métodos de inoculação de Azospirillum brasilense e sua influência na promoção de crescimento do milho. Dissertation (Master), Universidade Estadual do Oeste do Paraná, Marechal Cândido Rondon.

Cadore $\mathrm{R}$ et al. 2016. Híbridos de milho inoculados com Azospirillum brasilense sob diferentes doses de nitrogênio. Revista Brasileira de Milho e Sorgo 15:398-409.

Caprio CH. 2017. Interação de variedades de milho sob inoculação com Azospirillum brasilense em diferentes épocas de semeadura. Dissertation (Master), Faculdade de Ciências Agrárias e Veterinárias, Universidade Estadual Paulista, Jaboticabal.

CONAB - Companhia Nacional de Abastecimento. 2018. Acompanhamento de safra brasileira: grãos, intenção de plantio, oitavo levantamento/Companhia Nacional de Abastecimento. Brasília: CONAB, $142 \mathrm{p}$.

Corsini DCDC. 2018. Coberturas vegetais e modos de inoculação com Azospirillum brasilense em milho sobre três sistemas de preparo de solo. Thesis (PhD), Faculdade de Engenharia, Universidade Estadual Paulista, Ilha Solteira.

Costa RRGF et al. 2015. Efficiency of inoculant with Azospirillum brasilense on the growth and yield of secondharvest maize. Pesquisa Agropecuária Tropical 45:304-311.

Cruz CD. 2016. Genes Software - extended and integrated with the R, Matlab and Selegen. Acta Scientiarum 38:547-552.

Cunha FN et al. 2014. Efeito da Azospirillum brasilense na Produtividade de Milho no Sudoeste Goiano. Revista Brasileira de Milho e Sorgo 13:261-272.

Cunha FN et al. 2016. Performance of different genotypes of maize subjected to inoculation with Azospirillum brasilense. African Journal of Agricultural Research 11:3853-3862.

Dall'agnol A. et al. 2018. Azospirillum e a adubação nitrogenada em milho. Available at: https://blogs.canalrural.uol.com.br/embrapasoja/2018/ 05/15/azospirillum-e-aadubacao-nitrogenada-em-milho>. Access on: Sept. 24, 2018.

Dartora $\mathrm{J}$ et al. 2013. Adubação nitrogenada associada à inoculação com Azospirillum brasilense e Herbaspirillum seropedicae na cultura do milho. Revista Brasileira de Engenharia Agrícola e Ambiental 17:1023-1029.

Embrapa. 2009. Manual de métodos de análise de solo. 2.ed. rev. atual. - Rio de Janeiro. 627p.

Embrapa. 2013. Sistema brasileiro de classificação de solos. 3.ed. Brasília.

Köppen W, Geiger R. 1936. Handbuch der klimatologie. Gebrüder Borntraeger, Berlin.

Farinelli R, Cerveira Junior. 2015. Resposta de cultivares de milho transgênico e convencional a densidades populacionais. Revista Brasileira de Milho e Sorgo 13:336-346.

Ferreira LL et al. 2019a. Components of maize crop as a function of doses of polymerized urea. Journal of Agricultural Science 11:185-192.

Ferreira LL et al. 2019b. Bioestimulante e nitrogênio de liberação gradual no desempenho do sorgo. Nativa 7:330-335. 
Freitas RS et al. 2017. Desempenho agronômico de cultivares de milho na região norte/oeste do Estado de São Paulo - safras 2015/16 e 2016/17. Nucleus Ed.Especial:113-120.

Guimarães VF et al. 2014. Morphophysiological characteristics of maize inoculated with Azospirillum brasilense and Herbaspirillum seropedicae as seed treatment, cultivated in different types of soil. African Journal of Agricultural Research 9:2919-2924.

Kappes C et al. 2013. Inoculação de sementes com bactéria diazotrófica e aplicação de nitrogênio em cobertura e foliar em milho. Semina: Ciências Agrárias 34:527-538.

Kopper CV et al. 2017. Características agronômicas e produtividade de milho segunda safra em função da velocidade de semeadura e população de plantas. Pesquisa Agropecuária Pernambucana 22:e20170.

Lana MC et al. 2012. Inoculation with Azospirillum, associated with nitrogen fertilization in maize. Revista Ceres 59:399-405.

Lopes SJ et al. 2017. Relações de causa e efeito em espigas de milho relacionadas aos tipos de híbridos. Ciência Rural 37:1536-1542.

Matos FB et al. 2017. Uso de Azospirillum brasilense para o aumento da eficiência da adubação nitrogenada em milho. Revista Brasileira de Milho e Sorgo 16:131-141.

Morais TP et al. 2016. Inoculation of maize with Azospirillum brasilense in the seed furrow. Revista Ciência Agronômica 47:290-298.

Müller TM et al. 2016. Combination of inoculation methods of Azospirilum brasilense with broadcasting of nitrogen fertilizer increases corn yield. Ciência Rural 46:210-215.

Nardino M. et al. 2017. Divergência genética entre genótipos de milho (Zea mays L.) em ambientes distintos. Revista de Ciências Agrárias 40:164-174.

Possamai JM et al. 2001. Sistemas de preparo do solo para o cultivo do milho safrinha. Bragantia 60:79-82.

Quadros PD et al. 2014. Desempenho agronômico a campo de híbridos de milho inoculados com Azospirillum. Revista Ceres 61:209-218.

Ribeiro P. 2015. Bactérias aumentam produtividade do milho e reduzem adubos químicos. Available at: <https://www.embrapa.br/busca-denoticias/-/noticia/2467608/bacterias-aumentam-produtividade-do-milho-e-reduzem-adubos-quimicos>. Accessed on: Sep 25, 2018.

Silva EMS et al. 2015. Variabilidade de atributos físicos e químicos do solo e produção de feijoeiro cultivado em sistema de cultivo mínimo com irrigação. Revista Brasileira de Ciência do Solo 39:598-607.

Silva DFG et al. 2016. Genetic dissimilarity and definition of recombination clusters among green corn half-sib progenies. Bragantia 75:401-410.

Silveira DC et al. 2015.Caracterização agromorfológica de variedades de milho crioulo (Zea mays L.) Na região noroeste do Rio Grande do Sul. Ciência \& Tecnologia 1:01-11.

Spolaor LT et al. 2016. Bactérias promotoras de crescimento associadas a adubação nitrogenada de cobertura no desempenho agronômico de milho pipoca. Bragantia 75:33-40.

Taiz L et al. 2017. Fisiologia e desenvolvimento vegetal. Artmed Editora. 858p.

Valderrama, M et al. 2011. Fontes e doses de NPK em milho irrigado sob plantio direto. Pesquisa Agropecuária Tropical 41:254-263. 